\title{
Iowans in the Arts: Curtis Harnack
}

\section{Judith Gildner}

On October 11, 1974 Curtis Harnack was in Des Moines to receive the Johnson Brigham Plaque from the Iowa Library Association. He received the award for his latest book, We Have All Gone Away. I met with him prior to his appearance at the Association's Recognition Dinner and we talked about his youth in northwestern Iowa, his writing career, his books, and the Midwest traditions which have had an impact on his life and work.

CURTIS HARNACK WAS BORN IN LE MARS, Iowa in 1927 and grew up on a farm near Remsen in Plymouth County. In addition to the non-fiction work, We Have All Gone Away (1973), he has written three novels-The Work of an Ancient Hand (1960), Love and Be Silent (1962), and Persian Lions, Persian Lambs (1965). The last is a book about Iran, where he was Fulbright Professor of Literature at the University of Tabriz. Currently he is the director of Yaddo, the foundation for the arts in Saratoga Springs, New York.

Harnack left the state in 1949 to study at Columbia, returning in 1952 to teach and write at Grinnell College. Later he lived in the East, spending ten years in New York City. Growing up on a farm in northwestern Iowa provided Harnack with the material upon which much of his writing is based. In the two early novels and the recent autobiographical book, he draws heavily upon the rural Midwest environment. He said, "Moving back to a rural setting in upstate New York was largely responsible for We Have All Gone Away. After a decade of city life, I was again in touch with things important to me in childhood, and I wrote of that period without any sense of strain or distance." Harnack's family for 
generations farmed the land near his birthplace-the farmhouse he grew up in was handbuilt by his prairie sodbreaker grandfather.

The farm exacted hard work, and during his youth he came to understand the exigent nature of economic crises. He remembers the disruption of lives caused by families being uprooted from land that for decades had provided them with livelihoods. Conflict over the desire to remain near their origins and the need to make an adequate living for their families confronted many farmers during the 1930s. A character in The Work of an Ancient Hand, Henry Ketter, wants to remain on his farm but cannot pay the mortgage and painfully realizes that he must move his wife and two sons to the city in search of employment-an act totally foreign to his past experience. It is his firm conviction that being a farmer is "a man's work. It was better than anything else one might do. He would not have that grocer's job for anything, to say foolish things about the weather while dusting canned peas on a musty shelf; nor would he be a clever banker . . . who walked on marble tile all day." (p. 154) In the end, however, Ketter's family is going to have to leave the farm, and in reflecting on this sad fact he thinks of their unborn child, "heir of the winter; perhaps although born in some strange city, it would always sense a dim connection to a farm never seen." (p. 156) His wife is more willing than he is to give up the past, and his sons seem eager to go to school in the city where greater educational advancement is possible; therefore he becomes resigned to the eventuality that "the farm would be quickly abandoned in their expanding lives ... He would not force the farm on any of them, aware as he was now of their farther dreams." (p. 156)

Harnack remembers that another disruptive factor-violence - touched the lives of rural people during the Farmers' Holiday movement of the thirties. ${ }^{1}$ He wrote of this in We Have All Gone Away. "If we traveled beyond the sanctuary of our farm in 1932 and 1933, the automobile might be stopped by men waving pitch-

\footnotetext{
'Under the leadership of Milo Reno, former president of the Iowa Farmers' Union, the Farmers' Holiday Association was formed in an effort to stop the flow of farm products to market. Many farmers felt this step was necessary to halt the drastic price decline occurring in 1932-33. See Arthur M. Schlesinger, Jr.'s The Crisis of the Old Order, 1919-1933 (Boston: Houghton Mifflin Co., 1957), 265269.
} 


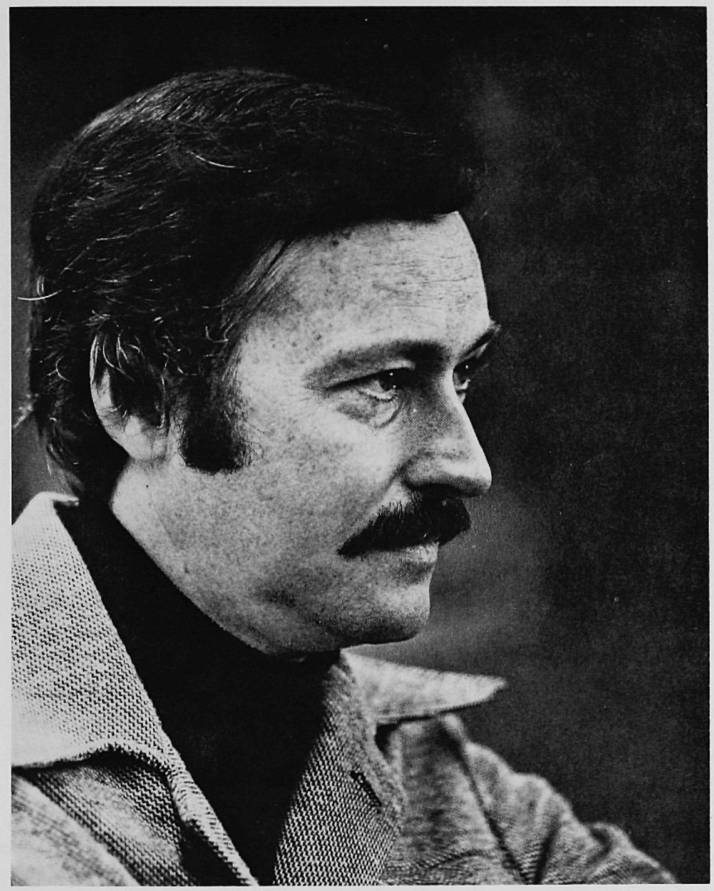

Photograph by Nicholas Sapieha

Curtis Harnack

forks. Uncle Jack would try to smile and familiarly called out their names, to weaken their unfriendliness. When the farm strikers saw the interior piled deep with children, not egg crates and cream cans, they dropped back into the ditch weeds. We rode past cars with trunks open for inspection and rear seats jerked out of place. The Farmers' Holiday picketeers were searching for produce that might reach market in defiance of their embargo. Creeks were cloudy with dumped milk cans and thousands of 
smashed eggs coated the roadside grass, at these checkpoints." (p. 125) A relative of Harnack was involved in a shooting: "Helped by a band of vigilantes, a grocer in a neighboring town had opened fire on August and other Holidayers when they tried to raid his store. 'Those law-and-order boys can't shoot too good!' His old, infectious giggle erupted, white teeth flashing." (p. 128)

The impact of the land has been lasting and meaningful to Harnack. He said, "Someone who grows up close to the soil is lucky because the unfolding of his life, into complexity, subtleties of thought and response, follows a natural development. I think it was the poet Edwin Muir who said that he who knows his own small village knows the whole world. A farm childhood makes it possible for one to grasp the essentials of life-birth, death, growth, health, disease, etc., - as facts. I think a city child is assaulted with complexity and might have a harder time sorting things out." In We Have All Gone Away, he wrote: "We were never far from the pleasure a plant took in growing, an animal in living. At night I'd stare heavenward at the curds of stars called the Milky Way. In a galaxy of such infinite milkiness, we were alive and attentive here at the nourishing breast of the world." (p. 76)

A child's security amidst the bounty of field and farmhouse kitchen did not discount the fact that life in rural Iowa in the 1930s was essentially closed to experience of the wider world. Many of the characters in The Work of an Ancient Hand and Love and Be Silent express a restlessness with what they consider an inane existence. Harnack mentioned that he remembers people near his home in Iowa who, once they retired from the farm, lived out their lives in boredom and morosity, having no purpose in life after their involvement with the farm was ended.

In The Work of an Ancient Hand this is illustrated quite vividly in the character of Herman Johns, a farmer who, having turned over his farm to his son, moves with his wife to town to live with her two unmarried sisters. Johns, feeling useless and bored, begins secretly to drink. But his malaise only increases after the death of the two sisters and his wife, Christine. The minister of the town fears for Johns, knowing that "there was a time each spring-usually in March-when aged farmers could not stand to witness another growing season in which they would have no part. Just when lawns began to turn green again and there was a stir of 
life and activity, suggestive of all that was to come, despairing old timers threw ropes around their necks. To a city person the bleakest time of the year is dead winter, but to these country people there was no period more terrible than the surge at the beginning of spring. No season more clearly foretold the end, and all of the years of green earth to come after each man's time." (pp. 223224)

Harnack believes it is important for people to have roots, to know where they came from. This, he feels, is the key to one's identity, and though often camoflaged, cannot be denied. He is drawn back to Iowa, not only to visit his uncle, cousins and other relatives, but because he remains close to the place that taught him certain truths.

When asked if he ever considered staying in Iowa, near the place of his birth, Harnack replied emphatically that he never considered staying once he recognized his inclinations toward writing and painting - at one time he had considered becoming an artist. His family encouraged his interests. His mother wanted him to do the things that fulfilled his ambitions. It was not until after he had left the state, however, that he was able to write about the Midwest experience.

"I was eager to get away from Iowa," Harnack said, "but in fact I've lived there most of my life. It was necessary to have some distance on the Midwest in order to write about it. I wrote parts of my first book in New York, in Wisconsin, in Saratoga Springs (summer of 1957, at Yaddo); I wrote the first draft of Love and Be Silent at Yaddo, summer of 1957, and did much re-writing in Iran, 1958-59, when I was a Fulbright Professor of American Literature at the University of Tabriz. I completed re-writes of Love and Be Silent in a flat on the Lower East Side of New York and in a shack outside our camp at Pownal, Vermont, summer of 1961. Now since I've written quite a bit, I don't think this removal is necessary. I may not write much about Iowa again-who knows? I may wish to return to live there; I think about the possibility with pleasure, quite a bit. Increasingly the people of Iowa strike me as a very unusual sort; one finds a lot of quality, of integrity, an arts interest-the kind of thing one used to associate with New England people."

Harnack pointed out that a great many people who are nurtured here eventually leave Iowa, pursuing cultural stimulation, 
education, employment, adventure; and of course some merely escape to milder climates. Often the reasons for leaving are tied to economic realities. California loomed large in the mind of the Middle West during the Depression years of the 1930s and early 1940s. An impulse to flee urged whole families to seek new starts and new identities in California which they perceived, not unlike the Joads in The Grapes of Wrath, as a sunny paradise of milk and honey. Harnack remarked that We Have All Gone Away, which concerns his early life in the Iowa of the thirties, has not enjoyed a very good sale in California-this despite the fact that there is a sizeable contingent of former Iowans living there. You would think they would be interested in nostalgic remembrances of their original home, he said, but apparently just the opposite is true; they have left and no longer want to be reminded of their former identity.

Harnack said he began writing stories while in the seventh grade of Remsen Junior High. He wrote a piece about a mouse which, when read aloud to the class, produced laughter. He was so pleased at being able to entertain his classmates that he felt encouraged to write more stories.

As a youth he read such classics as Crime and Punishment and Pere Goriot from the "Harvard Five Foot Shelf" collection in his farm home. He said that he "was puzzled but fascinated by Henry James' Portrait of a Lady . . . and I loved porch-reading of such popular stuff as Gone with the Wind and Valley of Decision (Marcia Davenport). Robert Louis Stevenson was a long-time favorite, since his Child's Garden of Verses. I was not a voracious reader in my youth, however. I read slowly and had trouble with the big words . . . and I read anything that came into the house, the novel supplements of American magazine and the Collier's fiction .... at times I felt hungry for more books than I could find anywhere ... but not too often."

He said his first deep appreciation of midwestern literature came in 1950 when he read Willa Cather's $O$ Pioneers!, A Lost Lady, My Antonia, and most of her other works. He was also fond of Mark Twain's Tom Sawyer and Huckleberry Finn, and while a student at Grinnell College (1944-45 and 1946-49) he read Iowa Interiors, by Ruth Suckow, and later The Folks. He said, "My reading was mostly general and not oriented to the Middle West, until I began to write and teach, in 1952, at Grinnell. I studied 
with Mari Sandoz at the University of Wisconsin the summer of 1950 , but I wasn't much interested in her work at that time. I've found that many students prefer not to read the work of their teachers, while in a classroom relation with them. Perhaps this is because the student doesn't want to be disappointed in the teacher's output, or overawed. This is particularly true of creative writing classes, where the student is trying to forge his own work in his own way.

"Later I became a great admirer of Old Jules, and still am. It can be disheartening to discover how much good work has been done in the very area where you yourself wish to be; for confidence and for growing one's own originality, a certain amount of distance seemed necessary, and therefore I didn't try to read everything written by middle westerners, nor have I read it now. When I was a student at Columbia, 1949-51, I was far enough away to safely take up Cather, Suckow, Garland. And of course, Hemingway and Fitzgerald are midwesterners too, often in subject, and certainly in prose style. I encountered Winesburg, Ohio in a paperback edition, fairly early on, perhaps when I was in college.

"In more recent years I've come to admire and read Wright Morris, Edward Dahlberg's Bottom Dogs, Julia Siebel's The Narrow Covering, Lois Phillips Hudson's, The Bones of Plenty, Tillie Olsen's work, James Purdy's The Nephew, and many others."

Religion was important in Curtis Harnack's boyhood. "We were Missouri Synod Lutherans," he said, "and strong church people. The Bible had a strong influence on me, and though I've left that particular denomination, I still have strong religious feelings. It's not institutionalized in any way, but it's there. I think the harshness of German Lutheranism had a bad influence on some members of my family (my mother in her later years felt oppressed by the church doctrine). But I think German authoritarianism was as much responsible as the fundamentalist faith itself. It was 'fear and love God,' with the emphasis on fear, making love impossible."

Living on a farm, close to nature's birth-growth-death cycle made people quite conscious of their dependence upon forces over which they had little or no control. Certainly, as Harnack pointed out, fear of the consequences of "bad" behavior was present in the lives of rural people. It was easy to make direct connections between a bad deed and the tornado sweeping across the prairie 
bringing punishment and/or warning.

Depending on weather and soil conditions, fearing disease to family, crops and livestock, and anxious over market price fluctuations, etc., farm people seemed to understand their vulnerability to the whims of nature and the economy. Harnack pointed out that city dwellers might forget, or never comprehend, the simple truths of human existence. In the city one sees tall buildings surrounded by other tall buildings and concrete, which can be interpreted as monuments to the glory of man's accomplishments. It is not so easy to revel in this feeling of false glory when living organisms, not concrete, are considered the measure of man's success or failure. Harnack recalled hearing the minister pray for rain to save the community from the peril of drought.

In Love and Be Silent a letter sent by Alma Larkin to her relatives in Iowa tells of hardships she and her husband endured on their North Dakota farm. These conditions could prevail in any midwestern state. "The grasshoppers came so thick and fast I thought they'd never leave until they'd gobbled us up, too. What the drought didn't finish off, the grasshoppers did. Every Sunday in church the minister would pray for rain, but it never came, and finally he asked God to send a flock of gulls. No, this isn't a Mormon church. Afterwards some of the people were grumbling because they thought he should have prayed for rain, instead of gulls. They didn't believe gulls would ever come-and they were right. No rain, either." (p. 135)

Religion isolated one group from another within a community. Almost all social activities were organized around the church, and this tended to keep Protestants and Catholics separate. Catholics were not liked or trusted, were even hated, by the majority Protestant population. In Harnack's novels about the Midwest religion is an important force directing the life of rural and town communities.

The Work of an Ancient Hand opens with the arrival of a new minister, Vernon Kallsen, and his wife to the town of Kaleburg. The town banker, Bill Wolbers, shows them around, apprising the Reverend of his duties to the community. "They drove up the wide, paved Main Street with its prosperous-looking stores and many, many taverns. Yes, the German Catholics saw no harm in liquor, said Wolbers - and they found ways of getting it. Even the priest liked his whiskey. The Catholics apparently tried to run 
everything in Kaleburg, 'but with you here, Reverend,' said Wolbers to Vernon, 'things might change, huh? Our other man just tucked himself in and didn't try to do much.' "' (pp. 17-18)

In politics Harnack said that his family, although at one time admirers of Herbert Hoover, turned to the Democrats during the 1930s and 1940s. "We were New Dealers," he said, ". . . supporters of Roosevelt-[we] had been Republican in the 1920s but hard times turned us Democrat. My mother was an internationalist, loved Britain, hated the Chicago Tribune and all it stood for. We subscribed to the New Republic and were liberally oriented. Politics was as personal as religion, however, and not discussed with strangers, particularly not with my aunts (my father's sisters) who were right-wing Republicans."

I asked Mr. Harnack to comment on the following statement: Writers of fiction often record the behavior, attitudes (religious, social, political), and "style" of a period. In a sense, therefore, they can be considered historians. He said, "I don't think writers who're novelists or so-called 'creative writers' should be conscious of themselves as historians. That's for critics to say about their work. If that element is too much present, a certain antiquarian quality comes into the work; no novelist should be so much bound to the facts of a time or place that he can't make the necessary connections, which would be 'truth,' in the Aristotilean sense of art as truth." He pointed out that the writer's artistic vision is not too concerned with accurate details. His two works of fiction set in Iowa in the 1930s and 40s reflect their author's intimate knowledge of the place and time. Yet they are not to be taken as documents reporting factual details and strict chronology. The truth about the Midwest in those decades, as revealed in The Work of an Ancient Hand and Love and Be Silent, is more complex and pervasive than any purely factual reconstruction of the period can be. The books present "reality" in terms of the intellectual, emotional, and visceral responses of people to circumstances, place, and time. Harnack feels that the writer should not be bound to research in order to make his settings. What he wants to give the reader is a sense of history. The writer, generally speaking, is concerned with his memory of people, places, and things; and his view may contain more valuable truths than the historian's methodically documented account.

In recreating a time and place, Harnack has effectively con- 
fronted the question of national, as well as regional, identity-the way Americans live, who we think we are and why, and how we assess our condition. Commenting on The Work of an Ancient Hand, critic Carlos Baker wrote, "Meticulously integrated as a mosaic, it presents in lucid prose a composite portrait of a whole community inside Iowa-farmers and bankers, the minister and mayor, the youthful lovers and the aged haters-with a triumphant mixture of compassion and wonder. . . . Although he knows and loves this rich land in all its moods and weathers, Mr. Harnack unremittingly focusses our attention where it belongs, on the sturdy German and Swedish people whose interwoven lives provide the factual substance of his book."

During our conversation Harnack said, "In We Have All Gone Away, which is not a novel, I tried to keep to the facts as memory put them. I had a lot of letters, obituaries, family stuff, for verifying dates. And even so, some members of my family have rather urgently pointed out mistakes I made. But since a narrator is present, clearly it's his tale, and his view of things; my siblings might've told a different tale, though we'd be bound by the outward history: the beginning of World War II, the farmer's rebellions in 1933, etc."

He believes that the most "alive" history is told through letters, diaries, and memoirs of those who speak with first-hand knowledge about the times they lived in. He is sometimes annoyed by historians who insist on adding theatrical narrative-such as describing a general pacing the floor of his private chamber the night before a battle. "How does the historian know that that general paced the floor?" 
Copyright of Annals of Iowa is the property of State of Iowa, by \& through the State Historical Society of Iowa and its content may not be copied or emailed to multiple sites or posted to a listserv without the copyright holder's express written permission. However, users may print, download, or email articles for individual use. 